\title{
HEALTH TOURISM IN ASIA: THE READINESS OF BALI'S HEALTH TOURISM*
}

\author{
Nararya Narottama, Ayu Susiyanthi. International Bali Institute of Tourism, \\ Sanjiwani General Hospital \\ naro_osh@yahoo.co.id
}

\begin{abstract}
The development of tourism in Indonesia, apparently affect the complexity of the needs of the tourists. Often while traveling, the travelers need an adequate health and/or medical infrastructures. For this reason, health tourism is a tremendous potential to be taken seriously. Unfortunately, not many hospitals in Indonesia's tourism destinations are ready for it. This study aimed to uncover, how the development of health tourism in Asian countries, and as a study in the future development of health tourism in Bali.

This preliminary research paper is qualitative study, uses descriptive literature approach. This research is very important, given that the development health tourism in Asia and Bali is essential. This study is also expected to be beneficial for the advancement of health tourism in Bali, as well as being a reference in the future study related to health tourism in Bali.
\end{abstract}

Keywords: health tourism, medical, tourism, Asia, Bali

\section{Introduction}

One form of recent global health care commercialization is medical tourism, health tourism, or medical travel (Alsharif, et al., 2010), some other terms are wellness tourism, healthcare tourism and global healthcare. It is possible to distinguish between health and medical tourism, especially in the scope of the targeted subject (supply), motive / desire of tourists (demands), and how serious the medical intervention in that context (Cook, 2010).

Although not all experts agree to combine the meaning of health and medical tourism, most definitions of health and medical tourism focused on the desire or motivation perceived by consumers / foreign patients back to their healthiness, as well as meet their secondary needs to gain travel experiences.

Medical tourism in a more specific to the medical treatment, medical action with provided medical facilities, more serious, structured and organized, including strict medical procedures and regulations. Meanwhile, health tourism has a broader scope, especially in a proactive effort to prevention, rehabilitation and maintenance of physical and mental health of individuals, more loose,

\footnotetext{
* This paper presented at the The 2nd Symphonit (International Symposium on Hospitality and Tourism), in STPBI Campus. Jalan Kecak No. 12,Denpasar, Bali, Indonesia, from July $22^{\text {nd }}$ to $23^{\text {rd }}$, 2016. The theme of the forum is "Embracing Diversity for Better Tourism Futures".
} 
flexible, as well as unique and authentic, it also based on the availability of resources to the specific location / destination that are not always available in the patient's country of origin.

In the 20th century, rich people from developing countries often travel to the developed countries to gain access and medical facilities that are considered more advanced and qualified than in their home country. But in today's developments, a shift, or can be referred to as 'reversal' in medical tourism; many rich people from developed countries actually prefer medical treatment in developing countries for various reasons (Lunt, et al., 2013: 6).

Along with the rising cost of healthcare / medical service in developed countries, resulting in a growing number of people chose to seek treatment in other cheaper countries. In addition to these reasons, the time to queue for non emergency medical services is a lot shorter in developing countries than in developed countries, also with patient's need for a new and fresh atmosphere. The key factors of health tourism in 21 th century, among others:

1. More and more people / tourists who travel for treatment (health or medical treatment)

2. Trend shift of patients from rich developed countries to less expensive developing countries to gain access to medical services.

3. The availability of information about affordable health facilities in various parts of the world, which is easily accessed via the Internet ( $\mathrm{ibid}$ )

In conventional tourism, tourists spent their holiday by traveling internationally, as well as tourists from the cold northern climate, will spend time at resorts in the south to enjoy the warm weather and sunbathing on the beach. Tourist products such as this is known as $4 \mathrm{~S}$, the Sea, Sun, Sand, Sex (Lowry 1993: 183 in Narottama, 2012) and now added with the Surgery (Connell, 2006; WTTR ITB Berlin, 2012: 23). It's expected influenced by the increasing awareness of the health of individuals, the need for good anger and stress management, and the desire to always look "in shape, young and beautiful"

Health tourism is the concept of traveling to a specific destination to take advantage of world-class healthcare opportunities offered by best and experienced healthcare professionals in a medical facility with the most advanced technology, complete privacy, affordable, and usually linked with family vacation package (Swain, Dindayal and Suprava Sahu, 2008).

Medical tourism is defined as the sum of all the relationships and phenomena resulting from a journey by people whose primary motive is to treat or cure a medical condition by taking advantage of medical intervention services away from their usual place of residence while typically combining this journey with a vacation or tourism elements in the conventional sense. (Voigt et al., 2010: 36 in Cook, 2010)

Health tourism refers to cross-border health care, which is often driven by various factors, including its competitive costs, avoid long queue or waiting time for treatment, or to obtain medical service that is not available in the their country. Most of these patients come from the United States, Canada and Western Europe countries, with their destinations in Asia, the Middle East and Latin America (Alsharif, et al. 2010: 316)

Health and / or medical tourism industry is part of niche tourism segments. It's beginning in the 1990s, which then expanded globally into a multi billion 
dollar industry. This industry is estimated to be worth 60 billion US \$ in 2007 and growing at about 20\% per year (Macready, 2007 in Cook, 2010). Based on the large amount of financial benefits offered by this industry, as well as growing numbers of international medical travelers, it is not surprising if the countries in the world are competing in this promising sector.

Various countries open its doors to health and/or medical tourism, not only in the American and European countries, but also in Asia, Middle East, Africa, Australia and New Zealand (Bookman and Bookman 2007; Jagyasi, 2010; Schult, 2006; Voigt et al., 2010; Woodman, 2007 in Cook, 2010).

Medical services offered are also very diverse, from superficial treatments (eg, facial and massage) to invasive and high risk surgery (eg, heart surgery and organ transplantation), or a combination of both (Cook, 2010).

The development of tourism industry in Indonesia, apparently affect the complexity of the needs of the tourists. Often while touring, the tourists need adequate health / medical infrastructure and facilities. But, not many hospitals in Indonesia's popular tourism destinations that is ready for it. Thus, health tourism is a tremendous potential to be taken seriously.

Countries in Asia were the first to introduce the international medical travel as health / medical tourism is Singapore, Thailand, Malaysia, followed by India and the Philippines, and lately South Korea and Taiwan. In all these countries, the government plays an important role in promoting their tourism medical sector (Leng, 2010). It is estimated that these Asia regions received more than 1.3 million medical tourists annually (WMDA, 2011)

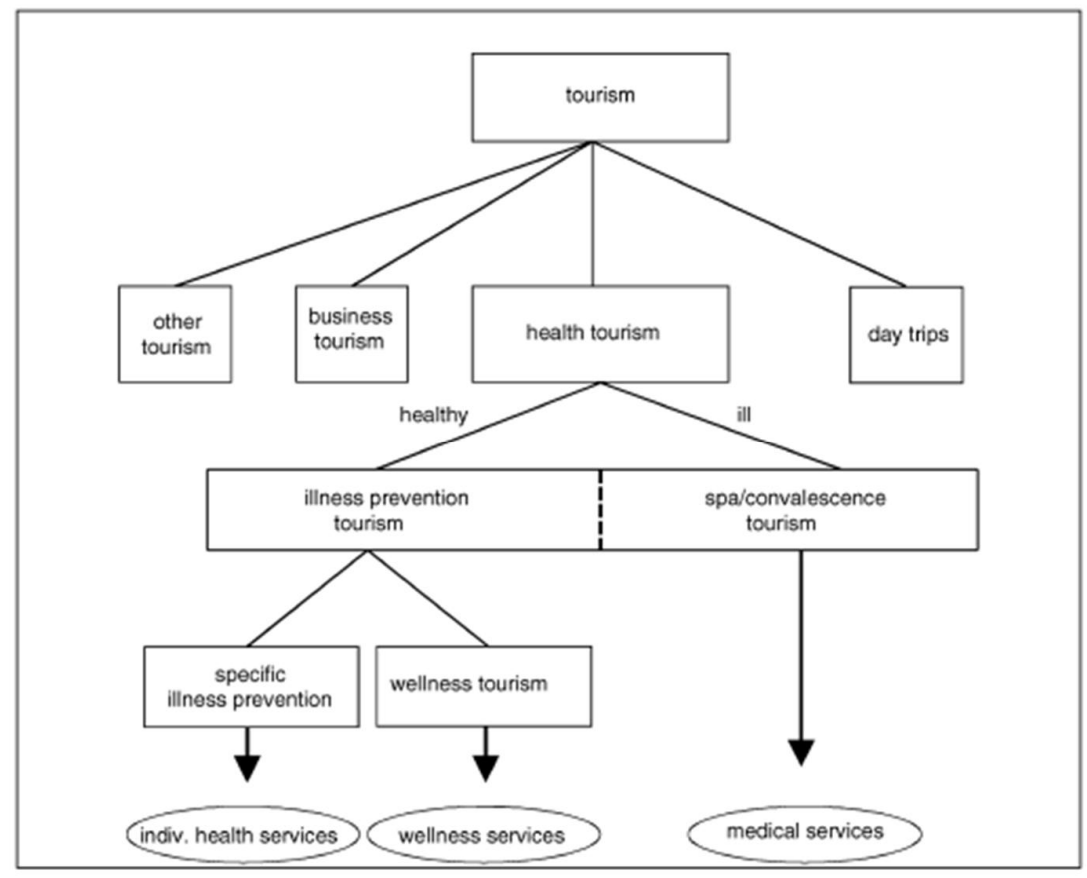

Wellness tourism hierarchy by demand (Mueller, et al. 2001)

Given the economic potential derived from this industry, health and/or medical tourism estimated will be the 'new business' with the fastest growth in the world (Chaudhuri, 2008). It facilitated by advances in transportation and medical 
technology, more affordable costs, and information availability via the Internet, as well as the rapid growth of the medical tourism industry broker. (Leahy, 2008). In addition, the growth of the middle class in developing countries is also affecting the rapid progress of this industry.

The rapid development of the health and/or medical industry, either public or privately owned, encourages the promotions of health tourism, and it becomes country's source of foreign currency income. Unfortunately, the international hospital in Bali is very limited, and this potential has not taken optimally. The only hospital in Bali that has been accredited by JCI (Joint Commission International - is an international hospital accreditation bodies, operating in more than 80 countries in the world) is Sanglah General Hospital, a Bali public hospital (JCI website in 2016).

\section{Health Tourism in Malaysia}

In 2015 and 2016, Malaysia won the prestigious rank as "Medical Travel Destination of the Year" of ITMTJ (International Medical Travel Journal) in a row. Earlier, Malaysia won the "Best Country in the World for Healthcare" by International Living's Annual Global Retirement Index 2014-2016.

A series of other achievements, Malaysia was named the "2013 Health Care Survey: The Best Havens for Quality Care Overseas" by top tourism magazine, International Living. In addition, one of the leading hospitals in Kuala Lumpur, the Prince Court Medical Centre, ranked first in Medical Travel Quality Alliance (MTQUA)'s "World's Best Hospitals for Medical Tourists" 2013. By these achievements, Malaysia is reasonably regarded as 'new power' in the global healthcare industry.

Chee (1990) in Leng (2010) states that the health care system in Malaysia can be described as a mix between private and public. In addition, the number of patients who use the services of health tourism showed an increasing trend. For comparison, in 2007, Malaysia received the 341,288 patients, in 2013, as many as 770,000 patients, and in 2015, more than 850,000 patients visited Malaysia from various countries. These data are come from 72 private clinics and hospitals listed in MHTC (Malaysia Healthcare Travel Council).

In 2006, Malaysia is expected to generate 59 million US\$ revenue (MTPB, 2008). The Association of Private Hospitals Malaysia projected that the number of foreigners who use medical care in Malaysia will grow in the range of $30 \%$ per year. Malaysia offers a wide range of services and medical procedures such as dental, cosmetic, and heart surgery at a cost much lower than the United States. 


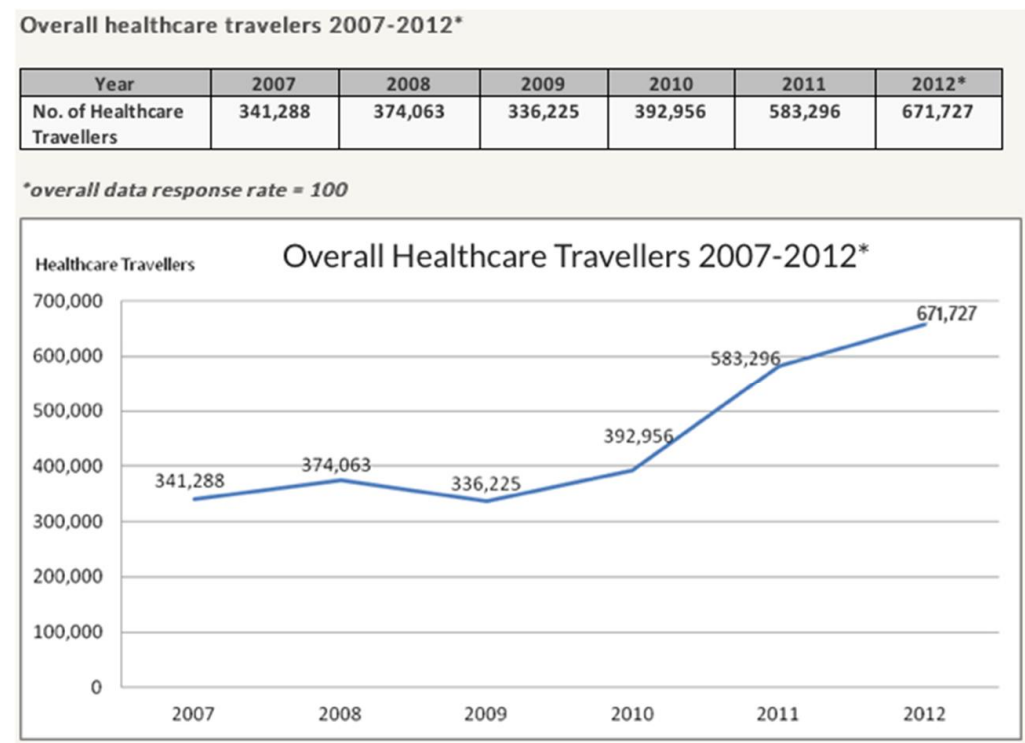

Statistic: Overal healthcare travelers in Malaysia 2007 - 2012 (MHTC, 2013)

The $\mathrm{Nu}$ Wire Investor (on line investment magazine) stated that health tourists and investors are interested in Malaysia's foreign exchange, economic, political stability and high literacy levels of foreign language (MTPB, 2008). This proves that Malaysia succeeded in developing world-class health tourism facilities. For Malaysia, this is a part of their remarkable achievements.

As for Indonesia, it becomes an irony, especially since many Malaysian physicians and medical professionals are studying in Indonesia (eg Faculty of Medicine, in Udayana University, Bali). On the other hand, the foreign patients in Malaysia hospitals are mostly from Indonesia, followed by Singapore, Japan and West Asia (Mun, Wong Kee \& Ghazali Musa. 2012). Especially for Bali, as the most popular tourism destinations in Indonesia and is well known in foreign countries, but has not been able to develop and maximize their health tourism segment.

There are several factors that make Malaysia as a popular health tourism destination in the world, among others:

1. High quality healthcare and service at low cost.

2. The ability to speak a foreign language (especially English).

3. Strong and consistent support from Malaysia government.

4. Aggressive and modern promotion.

5. Easier immigration process.

6. A wide selection of attractions and tourist destinations.

7. Availability of alternative treatments (Mymedholiday, 2013)

8. Accessibility and better transportation.

9. Synergy between sectors is mutually supportive.

Malaysia seems to prepare their health and /or medical tourism industry for a long time, including long preparation for the competent and qualified medical practitioners. Malaysia offers more affordable cost compared to Singapore, with the same type of treatment / care. Based on data from the Malaysian Health Care Travel Council, the cost of the most expensive heart 
bypass surgery ranges from $\$ 16,000$ USD in Malaysia, whereas in the US could reach $\$ 108,000$. A knee replacement surgery ranges from $\$ 8.400$ in Malaysia, and can reached $\$ 25,000$ in Australia for the same procedure.

\begin{tabular}{|c|c|c|}
\hline \multicolumn{3}{|c|}{ World's Best Hospitals for Medical Tourists 2013 } \\
\hline 1 & $\begin{array}{c}\text { Prince Court Medical Center, Kuala } \\
\text { Lumpur }\end{array}$ & Malaysia \\
\hline 2 & Asklepios Klinik Barmbek, Hamburg & Germany \\
\hline 3 & Clemenceau Medical Center, Beirut & Lebanon \\
\hline 4 & Fortis Hospital, Bangalore & India \\
\hline 5 & Wooridul Spine Hospital, Seoul & Korea \\
\hline 6 & Bumrungrad International, Bangkok & Thailand \\
\hline 7 & Anadolu Medical Center, Istanbul & Turkey \\
\hline 8 & Bangkok Hospital Medical Center, & Thailand \\
\hline 9 & Bangkok & Singapore \\
\hline 10 & Asian Heart Institute, Mumbai & India \\
\hline
\end{tabular}

Ref: MTQUA 2013 World's Best Hospitals for Medical Tourists.

Other supporting factors are the ability of its population in a foreign language. Most Malaysians are able to speak well English (EF-EPI, 2012: 4). At EF English Proficiency Index 2012, among 54 countries, with sample of nearly 2 million people, Malaysia won by 57.95 points (High Proficiency), while Indonesia gained 53.31 points (Low Proficiency). In health and/or Medical tourism industry, foreign language skills are essential to break down the cultural and language barriers, or the gap between medical personnel and its patients.

The Malaysian government strongly supports the development of health tourism in the country, and wants to create an image of Malaysia as an important health and/or medical tourism destination in Asia. To reinforce that image in the minds of tourists, the Malaysian government through the Ministry of Health Malaysia then set MHCT (Malaysia Health Care Travel Council) in 2009. To get closer and assist the medical tourists who come, then MHCT opened branches at Kuala Lumpur International Airport. In 2008, according to the magazine's website $\mathrm{Nu}$ Wire Investor, Malaysia is in the Top 5 Medical Tourism, with the order (1) Panama (2) Brazil (3) Malaysia (4) Costa Rica and (5) India. (Yanos, 2008).

\section{Health Tourism in India}

While in India, health and/or medical tourism industry is growing rapidly. In 2005, health tourism in India has been able to attract 150,000 foreign patients, and it is estimated that number will continue to increase in number of $15 \%$ per year, and is expected to generate up to 2 billion US \$ in 2012 (Hazarika, 2010). Based on data released by TMR (Transparency Market Research), India is the country with the highest growth of health and/or medical tourism industry in the world (TMR, 2015). India is also considered a center of world medical tourism, and the industry is able to improve the economy of 300 million US \$ in 2005 (Hutchinson, 2008), reached 2 billion US $\$$ in 2010, and estimated to be worth 2.2 billion US \$ in 2012 (Smith et al., 2009). Currently, India has 22 hospitals that have been accredited by JCI. 
In 2012, more than 400,000 foreign patients visit India for their medical care. This makes India as one of the countries most visited for medical travelers. India is a international medical tourism destination with world-class treatment, and very competitive rates. High-risk operations, such as heart bypass surgery can be $90 \%$ cheaper than in the United States (Bloomberg, 2013). Popular medical treatments in India among others: Cardiology, Neurology, Orthopedic, and Nephrology, reproduction, allergic, lungs etc. In addition, India is also known as the birthplace of the ancient Hindu medicine, the Ayurveda. Today, India is estimated has hundreds thousands of certified Ayurveda physicians.

Government of India support the growth of this sector by providing subsidies on tax and land concessions, special visa for medical tourists (the Indian government has removed visa restrictions, which limit for two months for consecutive visits, as well as the implementation of visa-on-arrival for tourists from certain countries that allow foreigners to stay for 30 days for medical reasons), international marketing of India as a country of world medical tourist destination, as well as bears the cost of physicians and healthcare professional training (Chanda, 2002). Most Indians master foreign languages, especially English. But if needed, hospitals in India will help to rent an interpreter (translator) to assist communication with foreign patients (Ghosal, 2013).

One of the cities in India that is considered as India's health capital (city of healthcare) is Chennai (Hamid, 2012). In Chennai, there are various multi and super specialist hospitals, and the estimated number of foreign patients who visit as many as 150 people per day. Chennai attracts around $45 \%$ of foreign patients, and $30-40 \%$ of domestic patients in India.

Not far from Chennai, there is a Sri Sathya Sai Institute of Higher Medical Sciences hospital in Anantapur District, Andhra Pradesh. Sri Sathya Sai Baba, a world famous spiritual leader in India, founded this hospital. The hospital is included in the category of 'super-specialist', especially for the field of cardiac surgery, internal organs and even plastic surgery. The doctors who work at this hospital is renowned physicians in India, they often writing in various world medical journals and be a speakers of international medical conferences. Uniquely, in this hospital, all the treatment is for free, and visitors are prohibited for wearing footwear inside the building.

However, the growth of health tourism in India is not always encouraging. The negative impacts on the growth of health and/or medical tourism are expected to raise the costs of domestic healthcare, limits healthcare access of poor communities, and fewer number of medical and/or health professionals, particularly in the public sector. Fortunately, the rapid growth of health tourism in India is considered able to pull back the immigrants of India (Indian diaspora) who is a doctor, where previously many doctors (who have recently graduated or specialist) went to more advanced and high income countries. (Hopkins et al., 2010).

\section{Health Tourism in China}

In China, the health system is under intense scrutiny since the introduction of market reforms in the late 1970s (Ma, Lu and Quan, 2008). The central government bears the responsibility of health care for the local communities in the region. (Hsiao, 2008). However, the inadequacy of local taxes forced many health 
centers and hospitals adopt the profit-oriented model to reimburse their medical expenses, and then charge it to the public. The poor are increasingly mired in poverty, which ultimately lowers economic growth in China. (Liu et al., 2003). Nowadays, China is facing the same problems with India; the lack of availability of medical personnel, with a ratio of 1.5 doctors and 1.1 nurses per 1000 population, mostly concentrated in Beijing and Shanghai.

Apparently, the growth of health tourism in China exacerbates the situation, especially for the poor in rural area. Many doctors and nurses more focus on foreign patients in city's modern health facilities. Although the Chinese government has increased the budget for health, but the economic motive in the health care system may affect the market that have been developed over the last three decades (Hsiao, 2008).

\section{Health Tourism in West Asia (Jordan and the United Arab Emirates)}

In Jordan, the Association of Private Hospitals (Private Hospitals Association) reported that, estimated at 210.000-250.000 foreign patients have been treated at 44 registered hospitals. Most of the foreign patients come from the surrounding Arab countries, and approximately 3,400 patients from the United States, Britain and Canada. This country has a scale of 5.6 doctors / nurses per 1000 population, and spend more than $10 \%$ of its GDP in health sector, surpassing other developing countries. (Vequist, 2009). Health tourism industry in Jordan reportedly brought revenues of 1 billion US \$ per year, with growth of $10 \%$ or more (Vequist et al., 2009).

Among some of the above countries, the United Arab Emirates (The United Arab Emirates-UAE) is an anomaly. Country UAE is considered as a country with income / high income, but has a spending budget for the health sector lower, ie $0.6 \%$ of GDP and 7\% of the total public expenditure in 2002. (WHO-EMRO, 2006). UAE state still seeks to grow its health tourism market by develop a 'Healthcare City' in Dubai, with a budget of 500 million US\$. The 'Healthcare City' will be dedicated to the treatment of foreign patients.

\section{Economic Benefits in Health Tourism}

Whittaker (2008) in Cook (2010) asserts, that the expected economic benefits of health and / or medical tourism increasingly sharpened the rivalry between the developed and developing countries. The medical tourism service providers need to find new ways to differentiate their services and facilities of other service providers, in their efforts to attract medical tourists.

As a result, local medical tourism services providers try to market their identity as 'specialization', and also their uniqueness in the target market. For example, medical services in Thailand promote wellness and cosmetic tourism, targeting patients who want plastic surgery, dental care, and genitalia surgery. India focuses on orthopedic, cardiovascular and cosmetic surgery. While some countries focus on their neighboring countries or countries close to them. Poland and Hungary are common destinations for dental care for residents of the UK and Germany, and Mexico is a favorite destination for Americans for dental care and medicine. (Hansen, 2008; Ramirez de Arellano, 2007 in Cook, 2010). Various examples above demonstrate how a destination tries to be 'authentic' by giving 'stamp' for them selves (self-branding). 


\begin{tabular}{|c|c|}
\hline Foreign Hospitals & Type of Hospital \\
\hline \multicolumn{2}{|l|}{ 1) Asia: India } \\
\hline Fortis Escorts Heart Institute & Part of a privately owned chain of hospitals \\
\hline $\begin{array}{l}\text { Apollo hospitals Group } \\
\text { Wockhardt Hospitals Group }\end{array}$ & $\begin{array}{l}\text { A privately owned chain of hospitals } \\
\text { A privately owned dhain of hospitals (affiliated with US-based Harvard } \\
\text { Medical International) }\end{array}$ \\
\hline \multicolumn{2}{|r|}{ 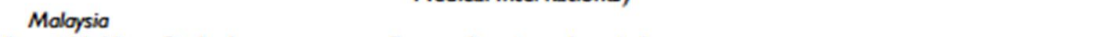 } \\
\hline Pantai Holdings Berhad & For-profit private hospital \\
\hline Penang Adventist Hospital & $\begin{array}{l}\text { Part of Adventist Health System, a chain of US-affiliated, religious-based } \\
\text { private hospitals }\end{array}$ \\
\hline $\begin{array}{l}\text { Prince Court Medical Centre } \\
\text { Singopore }\end{array}$ & For-profit private hospital \\
\hline $\begin{array}{l}\text { Johns Hopkins Singapore Interna- } \\
\text { tional Medical Centre }\end{array}$ & US-affiliated hospital (Johns Hopkins International) \\
\hline $\begin{array}{l}\text { National Healthcare Group } \\
\text { Parkway Health Group }\end{array}$ & $\begin{array}{l}\text { Chain of public hospitals } \\
\text { Chain of private hospitals }\end{array}$ \\
\hline Raffles Medical Group & For-profit private hospital \\
\hline $\begin{array}{l}\text { SingHeal th Group } \\
\text { Thailand }\end{array}$ & Chain of public hospitals \\
\hline Bumrungrad International & For-profit private hospital \\
\hline Samitivej group of Hospitals & Consortium of private hospitals \\
\hline $\begin{array}{l}\text { 1) Central and Sauth America: } \\
\text { Costa Rico }\end{array}$ & $\begin{array}{l}\text { Part of International Hospital Corporation, a chain of US-affiliated, for- } \\
\text { profit private hospitals }\end{array}$ \\
\hline Hospital CIMA, San Jose & $\begin{array}{l}\text { For-profit private hospital (affiliated with Mount Sinai Hospital, Florica, and } \\
\text { Tulane Medical Center, New Orleans) }\end{array}$ \\
\hline \multicolumn{2}{|l|}{$\begin{array}{l}\text { Hospital Clinica Biblica } \\
\text { Mexico }\end{array}$} \\
\hline $\begin{array}{l}\text { Christus Muguerza Group } \\
\text { Hospital San josé Tec de, } \\
\text { Monterrey }\end{array}$ & $\begin{array}{l}\text { Religious-based group of private hospitals } \\
\text { For-profit private hospital }\end{array}$ \\
\hline 1) The Middle East Jordan & \\
\hline $\begin{array}{l}\text { Ál - Essra Hospital } \\
\text { King Hussein Cancer Center }\end{array}$ & For-profit private hospital \\
\hline $\begin{array}{l}\text { King Hussein Cancer Center } \\
\text { Turkey }\end{array}$ & For-profit private hospital \\
\hline Acibadem Hospital Group & Chain of private hospitals \\
\hline $\begin{array}{l}\text { Anadolu Medical Center } \\
\text { United Arab Emirotes }\end{array}$ & US-affiliated private hospital (Johns Hopkins International) \\
\hline American Hospital, Dubai & For-profit private hospital \\
\hline University Hospital, Dubai & $\begin{array}{l}\text { University research hospital; US affiliated private hospital (Harvard Medical } \\
\text { International) }\end{array}$ \\
\hline Po & Foreign Healthcare Provider \\
\hline
\end{tabular}

Ref: Gan, Lydia L. and James R. Frederick. 2011

\section{A Critical Factor in the Development of Health Tourism in Bali}

With the number of visits of more than three million people each year, Bali is the biggest tourist destinations in Indonesia. Bali has great potential for the development of health and medical tourism industry. A good blend between society, culture and nature has created a perfect atmosphere for the development of this industry.

Improved service and quality is an absolute thing that must be fulfilled in the development of health tourism in Bali, by raising the number of specialist doctors and medical professionals, as well as adding standard medical equipment. Successful health and/or medical tourism industry cannot be separated from the political and economic stability, the government's full support, well as the interference of private investors. Tourists from developed countries would choose a hospital that has a reputation for excellent quality and service, although they must pay higher.

A hospital's reputation associated with the level of service excellence in serving the needs of patients professionally (according to international standards, effective and efficient), in line with norms, ethics, law and the local culture, as well as efficiently use of resources and fair financing. This can only be done through the fulfillment of international accreditation and quality assurance. 
Improved medical facilities has also become one of the key factors in the future development of health tourism in Bali. An excellent service (professional, wholeheartedly and oriented to the patient) will be able to attract new patients and maintain their loyalty. The transparency between hospitals with the patients is a must (e.g. no hidden fees), as well as hospital cleanliness, with sympathy, courtesy and hospitality of the medical staff towards patients and their family.

The lack of foreign language skills, particularly English, is often an obstacle in communication with foreign patients. Language barriers should be minimized by providing foreign language education for medical personnel, especially for officers who interact directly with patients. Responsive medical personnel with good communication skills will avoid language barriers. Health tourism travelers choose the hospital with good foreign language skills, as they relate to communications and medical services, especially in urgent or critical situation. In addition to English as the main language, is required of other languages that support, such as French, Japanese, Korean, Russian, Chinese and others.

WoM (Words of mouths), is still an effective strategy in the international marketing. News, positive or negative, on a medical service, will quickly spread in the international community, particularly through Internet (e.g. articles, blogs, forums, mailing lists). The foreign patients, especially those who are new in terms of choosing medical services, tend to listen to the information and recommendations made by family and friends. Thus, a good reputation is absolute. To gain market share globally, a modern international marketing methods should be applied, particularly via Internet and a network of medical cooperation (e.g insurance agencies, international medical network). Increased flows of international patients also automatically increase the reputation and prestige of destination.

In the future development of health tourism in Bali, it is important to pay attention to local values (authenticity) in line to the principles of international services, among others:

1. The simplicity of service flow (quick, concise, easy to understand and straightforward service procedures).

2. Clarity, both technical and administrative requirements, also includes details of the cost.

3. Certainty of time, where the service implementation can be completed in accordance with the deadline specified.

4. Accuracy, health services can be implemented properly, correctly and legally.

5. Security, the implementation of the service is able to provide security and legal certainty.

6. Responsibility, the organizers responsible for conflicts, complaints and problems in the health care process.

7. Completeness of facilities and infrastructure, including medical equipment and technical equipment to the means of telecommunications and technologies.

8. Disciplinary, politeness and friendliness, is an important attitude that should be owned by every medical professional and other supportive personnel.

9. Comfort and cleanliness, the service environment should be clean, neat and comfortable, and gives the feeling of supporting the patient's recovery. (addaptation from Penyelenggaran Pelayanan Publik, in Kepmenpan No. 
63/Kep/M.PAN/7/2003 about Pedoman Umum Penyelenggaraan Pelayanan Publik - General Guidelines for the Implementation of Public Service.).

\section{Conclusion}

Health and/or medical tourism travellers have a wide choice of health care around the world. They can get information through the Internet with ease, although sometimes the information they receive is confusing and often wrong. The use of Internet in this case becomes very vital. An official website will form a reliable reference source for prospective patients, especially if the candidate coming from other countries.

Therefore, prospective foreign patients need to know about the facilities and health services or medical destination they want to go, based on information that is accurate and trustworthy. They will seek as much information as possible that will answer their curiosity about the quality and the best medical standard offered by the health care provider. However, although the information from the Internet widely available, a hospital accreditation status and recommendation by word of mouth from family and friends remain a major concern in choosing a hospital of their choice.

Important issues such as security and patient safety, legal protocols and operations, marketing integrity, transparency, and reviews from other users, receive attention from prospective patients. Other main issues are: the immigration process, the availability of travel and accommodation in the destination, hospital information, language and communication. To obtain maximum benefit, a health travelers should use a good and reliable medical tourism provider, which provide well trained facilitators, including being able to help overcome the problems that may arise during the process. Patient's safety is a critical issue in the implementation of health tourism in Bali. It is of course to avoid legal conflict in future. Hospitals also should be able to maintain the privacy of patients and their families.

In addition to meeting international standards and accreditation procedures, the hospital must have professional management. As well as a good partnership with international medical network will greatly help the development of health tourism in Bali.

The competition in this business in growing fast, as well as patient's shifted their paradigm to an "authentic experience". Therefore, the Bali's authenticity needs to be maintained in order to obtain a value differentiator with other competitors. Bali's authentic health program could be featured as: Balinese SPA, stress and anger management, lifestyle changing program, meditation, yoga, bio-energy, hypnosis, aroma therapy, massage, relaxation, inner power, prana (energy healing), crystal-medic, acupuncture, acupressure, reflexology, spiritual retreats, organic - herbal medicine, home care and special assistance to help elderly patients, thalassic and thermal / mineral cure which combined with Bali's local the philosophy and values.

\section{REFERENCES}


Alliance, The Medical Travel Quality. 2013. MTQUA 2013 World's Best Hospitals for Medical Tourists. http://www.mtqua.org/providers/top-10worlds-best-hospitals-for-medical-tourists-list/

Alsharif, Mohd Jamal et al. 2010. 'Patients beyond borders: A study of medical tourists in four countries'. in Global Social Policy 2010 vol. 10: 315 http://gsp.sagepub.com/content/10/3/315 visited 4 September 2013

Alsharif, Mohd Jamal, Ronald Labonté dan Zuxun Lu. 2010. 'Patients beyond borders: A study of medical tourists in four countries'. Global Social Policy 2010 Vol. 10: 315 in http://gsp.sagepub.com/content/10/3/315

ARSADA. 2014. Medical Tourism Trend. http://arsada.org/index.php/8-artikel/28 medical-tourism-trend visited 23 September 2013

Berlin, Messe. 2012. ITB World Travel Trends Report December 2012. Messe Berlin GmbH: Germany hal. 29

Bloomberg. 2013. International medical tourism industry pegged at $\$ 40$ billion a year. The Economic Times. http://articles.economictimes.indiatimes.com/2013-06-

27/news/40233610_1_medical-tourists-weight-loss-surgery-health-care visited 4 September 2013

Board, Malaysia Tourism Promotion. 2008. Malaysia Among World's Top 5 Medical Tourism Destinations. Press Release. Advertising \& Publicity Division, Tourism Malaysia http://corporate.tourism.gov.my/mediacentre.asp?page=news_desk\&subpag e=archive\&news_id=16 visited 1 September 2013 dikunjungi tanggal 1 September 2013

Chanda, R. 2002. 'Trade in health services'. Bulletin of the World Health Organization Vol. 80: 158-62 in Alsharif, et al. 2010 Loc., Cit., p: 327

Chaudhuri, S. K. 2008. 'Ethics of medical tourism'. in Journal of the Indian Medical Association. Vol. 106: 188

Chee. H. L 1990. Health and Health Care in Malaysia: Present Trends and Implications for the Future. Institute for Advanced Studies, Monograph Series No. 3. Kuala Lumpur: University of Malaya Press.

Connell, John. 2006. 'Medical Tourism: Sea, Sun, Sand....Surgery'. in Tourism Management 27 (2006) 1093-1100

Cook, Peta S. 2010. 'Constructions and Experiences of Authenticity in Medical Tourism: The Performances of Places, Spaces, Practices, Objects and 
Bodies'. The Tourist Studies 2010 Vol. 10: 135 dalam http://tou.sagepub.com/content/10/2/135

EF EPI. 2012. English Proficiency Index. English First. hal 4

Gan, Lydia L. and James R. Frederick. 2011. Medical tourism facilitators: Patterns of service differentiation. in Journal of Vacation Marketing 2011 17: 165 online: http://jvm. sagepub.com/content/17/3/165

Ghosal, Aniruddha. 2013. 'Medical translators to aid foreign patients'. The Times of India. http://articles.timesofindia.indiatimes.com/2013-0124/noida/36525978_1_medical-tourism-patients-medical translators visited 4 September 2013

Hamid, Zubeda. 2013. The medical capital's place in history. in The HinduChennai. http://www.thehindu.com/news/cities/chennai/article3796305.ece visited 4 September 2013

Hansen, F. 2008. 'A revolution in healthcare: Medicine meets the marketplace', IPA Review Vol. 59(4): 43-45 in Cook, Peta S. 2010 Op. Cit

Hazarika, I. 2010. Medical tourism: Its impact on the health workforce and health systems in India. Health Policy and Planning Vol. 25: 248-251 in Alsharif, et al. 2010 Loc., Cit., pp: 327

Hopkins L, Labonté R, Runnels V, et al. 2010. 'Medical tourism: What's the state of existing knowledge?' Journal of Public Health Policy Vol. 31: 185-198 in Alsharif, et al. 2010 Loc., Cit., hal: 327

Hsiao,W. 2008. 'When incentives and professionalism collide'. Health Affairs Vol. 27: 949-951. in Alsharif, et al. 2010 Loc., Cit., hal: 327

Hutchinson, J. 2008. 'Medical tourists from around world flock to India', Rocky $\begin{array}{llll}\text { Mountain News, } & 26 & \text { Februari } & 2008\end{array}$ www.rockymountainnews.com/news/2008/feb/26/medical-tourists-fromaround-world-flock-to/ visited 4 September 2013

India Health Visit. 2013. Chennai - India's Health Capital http://www.indiahealthvisit.com/chennai-health-capital.htm visited 4 September 2013

ITBBerlinhttp://www.itbberlin.de/media/itbk/itbk_media/itbk_pdf/WTTR_Report _2013_web.pdf visited 1 September 2013

Leahy, A. L. 2008. 'Medical tourism: The impact of travel to foreign countries for healthcare.. Surgeon. Vol 6: 260-261. 
Leng, Chee Heng. 2010. 'Medical tourism and the state in Malaysia and Singapore'. Global Social Policy 2010 10: 336 online http://gsp.sagepub.com/content/10/3/336

Liu Y, Rao K, and Hsiao W. 2003. 'Medical expenditure and rural impoverishment in China'. Journal of Health, Population and Nutrition Vol. 21: 216-222. in Alsharif, et al. 2010 Loc., Cit., hal: 327

Living, International. 2013. Health Care Survey: The Best Havens for Quality Care Overseas. http://internationalliving.com/2013/04/health-care-surveythe-best-havens-for-quality-care-overseas/ dikunjungi tanggal 30 Agustus 2013

Lowry, L. (1993). 'Sun, sand, sea \& sex: a look at tourism advertising through the decoding and interpretation of four typical tourism advertisements' in K. Chon, (ed.), Proceedings of Research and Academic Papers, Vol. V, The Society of Travel and Tourism Educators, Annual Conference 14-17 October, Miami

Lunt, Neil. et al. 2013. Medical Tourism: Treatments, Markets and Health System Implications: A scoping review. p:6. OECD. Directorate for Employment, Labour and Social Affairs http://www.oecd.org/els/healthsystems/48723982.pdf

Ma J, Lu M. dan Quan H. 2008. 'From a national, centrally planned health system to a system based on the market: Lessons from China'. Health Affairs vol 27: 937-948. dalam Alsharif, et al. 2010 Loc., Cit., hal: 327

MacReady, N. 2007. 'Developing countries court medical tourists', Lancet 369 (9576): 1849-1850. in Cook, Peta S. 2010. Op. Cit

Malaysia Healthcare Travel Council (Official Website) http://www.mhtc.org.my/en/statistics.aspx dikunjungi pada 30 Agustus 2013

Malaysia Tourism Bromotion Board (2008) : Malaysia In World Top Five Medical Tourism Destinations http://www.tourism.gov.my/news/trade/view/malaysia-in-world-top-fivemedical-tourism-destinations

Mueller, Hansruedi dan Eveline Lanz Kaufmann. 2001. 'Wellness tourism: Market analysis of a special health tourism segment and implications for the hotel industry'. Journal of Vacation Marketing 2001 7: 5 versi online: http://jvm.sagepub.com/content/7/1/5

Mun, Wong Kee \& Ghazali Musa. 2012. C. Michael Hall, ed. Medical Tourism: The Ethics, Regulation, and Marketing of Health Mobility. London: Routledge. p. 176. ISBN 978-0-415-66575-9. 
Mymedholiday. 2013. Malaysia's Got What It Takes To Become A Leading Medical Tourism Destination http://www.mymedholiday.com/blog/index.php/2013/08/690/malaysias-gotwhat-it-takes-to-become-a-leading-medical-tourism-destination/ visited 30 Agustus 2013

Narottama, Nararya. 2012. Spiritual Tourism: Case Study Of Foreigners Participation In The Pitrayajña Ceremony In Muncan Pakraman Village, Selat, Karangasem, Bali. Thesis. Master of Tourism Research. Udayana University, Bali and Université Paris 1 - Pantheon Sorbonne, Paris

Ramirez de Arellano, A. B. 2007. 'Patients without borders: The emergence of medical tourism', International Journal of Health Services Vol. 37(1): 193198. in Cook, Peta S. 2010 Op. Cit

Richter, Linda K. 2003. 'International Tourism and its Global Public Health Consequences'. Journal of Travel Research 2003 41: 340. online http://jtr.sagepub.com/content/41/4/340

Smith, R. D., R. Chanda and V. Tangcharoensathien (2009) 'Trade in healthrelated services', Lancet 373 (9663): 593-601. in Cook, Peta S. 2010 Op. Cit

Sri Sathya Sai Institute of Higher Medical Sciences http://psg.sssihms.org.in/index.htm dikunjungi tanggal 4 September 2013

Swain, Dindayal dan Suprava Sahu. 2008. Opportunities and Challenges of Health Tourism in India. Conference on Tourism in India - Challenges Ahead. Part XI - Health, Spiritual and Heritage Tourism. http://dspace.iimk.ac.in/bitstream/2259/590/1/475-484.pdf visited 2 September 2013

TMR (Transparent Research Market). 2015. India Leads Global Medical Tourism Industry thanks to Presence of Advanced Medical Technologies http://www.transparencymarketresearch.com/pressrelease/medicaltourism.htm

Vequist D, Bolatkale E and Valdez E (2009) Health tourism economic report, Jordan. www.healthtourismmagazine.com/article-detail.php?issue=issue$2 \&$ article $=$ Health-Tourism-Economic-Report. dalam Alsharif, et al. 2010 Loc., Cit., pp: 328

Vequist, D. 2009. 'Medical tourism economic report: Jordan'. Medical Tourism Magazine Vol. 12: 32-34. in Alsharif, et al. 2010 Loc., Cit., hal: 328

Voigt, C., J. Laing, M. Wray, G. Brown, G. Howat, B. Weiler dan R. Trembath. 2010. Health Tourism in Australia: Supply, Demand and Opportunities. Gold Coast: CRC for Sustainable Tourism. in Cook, Peta S. 2010 Op. Cit 
West Mediteranian Development Agency. 2011. Health Tourism Sector Report 2011.p. 9

Whittaker, A. 2008. 'Pleasure and pain: Medical travel in Asia', Global Public Health Vol. 3: 271-290 in Cook, Peta S. 2010 Op. Cit

World Health Organization - EMRO (Eastern Mediterranean Regional Office). 2006. Country cooperation strategy for WHO and the United Arab Emirates 2005-2009. EM/ARD/015/E/R. in Alsharif, et al. 2010 Loc., Cit., pp: 329

Yanos, Melana. 2008. Top 5 Medical Tourism Destinations : Medical tourism can mean attractive opportunities for foreign patients and investors. http://www.nuwireinvestor.com/ articles/top-5- 